\title{
醬油の香氯成分に就て（第二報) 醬油中の含硫香氮物賢の分離及び合成
}

\author{
(昭利十一年六月五日受領 昭利十一年八月廿五日印刷)
}

赤堀四郎金子武夫

第一報に於て著著の一人赤归は醬油の揶發性成分中にフルフロール，アセトイン，アセトアルデヒ ド及インヴアレルアルデヒドの存在を確かめ且つ醋酸ェチルェステルの存在を推定したが, これらの 物質を混合しただけでは決して醬油から分離したものの樣な强烈な香临を生じないので, 他に重要な

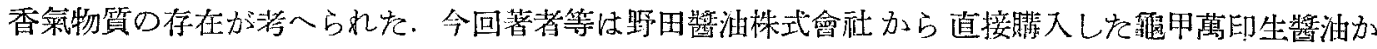
ら興味ある物質を分離し，且つそれを合成することが出來えからここに報告する。

醬油の香氣成分を探取するに水蒸蕒蒸溜及び有機溶媒による抽出の二つの方法が從來朋ひられて

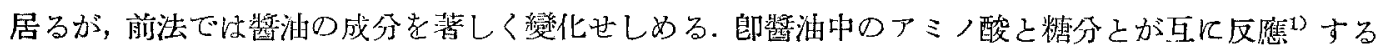
結果原醬油中に存在し疼かつた多量のアルデヒドが發生する.このととは次圖示す醬油中のアル デヒド蒸溜曲線及溜出液の再蒸溜に於けるアルデヒド蒸溜曲線の比較によつて明かである.

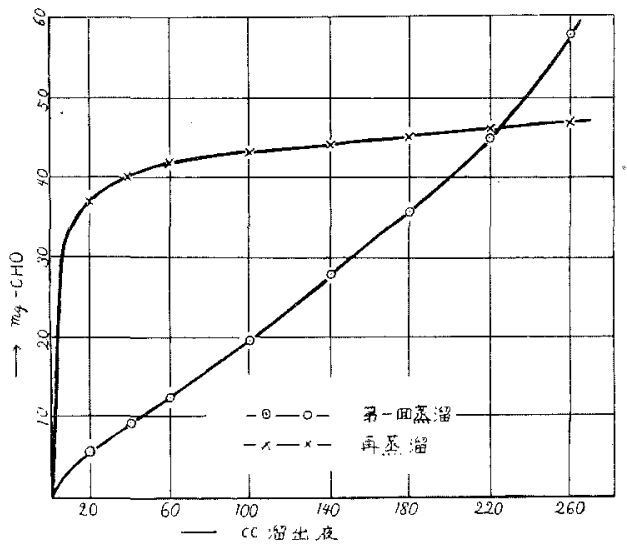

圖

まれ醬泊を倠機溶媒で抽出すれば多量の不揮發 性物質が混合して來る爲に香氣物質の精製因雖 にする，故に著者等江醬油老 $20 \sim 30 \mathrm{~mm}$ の減壓の 下K $60^{\circ}$ 以下で烝溜し, 溜出液ふ氷で泠却して探 取した.この溫度ではインヴアレルアルデヒドの 生成は極めて少い，溜出液から香氣成分を筷一報 の場合と同樣にして得をるのを分別蒸溜し沸點 54〜 60\% $15 \mathrm{~mm}$ の區分中に注アセトイン及乳酸エ チルェステルを檢出し得を．沸點 $63 \sim 87^{\circ} / 15 \mathrm{~mm}$ 及 $74 \sim 88^{\circ} / 4 \mathrm{~mm}$ の區分は香氣が最も强く且つ硫 黄を含倠して居ることを知つた。この含硫化合物

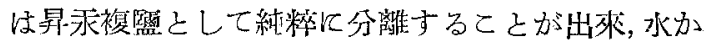
ら美しい稜杜状結晶として析出する。この複監を 再び分解して純粹な香氣物質を作り得方程の量が得られなかつたので複辟のまま分折した。水銀を 含む有機化合物の炎水秦の微量分析には通常の Pregl 式然燒管は用ひ得度へので吾ふが最も苦心し

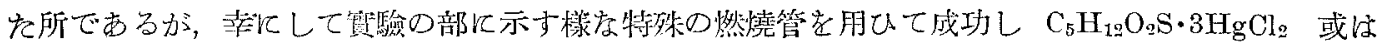

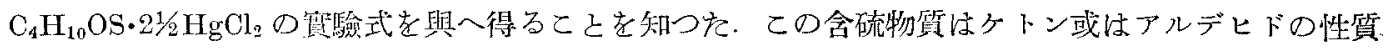
を示さ和, 沃度フォルム反應全く㓌性で, またアルカリ溶液がニトロプルシドナトリウムによりて着 巴世奴こよから硫黄はェーテル状に結合して居ることを知つた. Micro-Zeisel法によつてアルキルォ

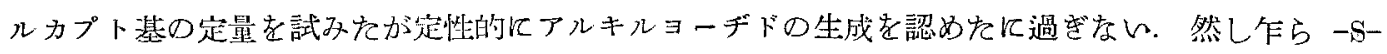

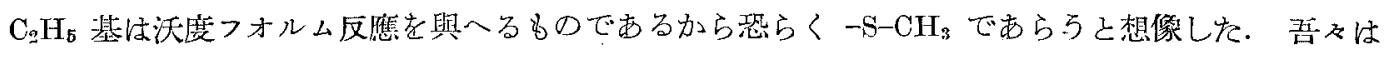

1）赫堀, 本誌, 52(1931), 606 . 
最初上記の昇承複櫨飞 $\mathrm{C}_{5} \mathrm{H}_{12} \mathrm{O}_{2} \mathrm{~S} \cdot 3 \mathrm{HgCl}_{2}$ の分子式を與へた爲にアルキルメルカプト基を有する數種

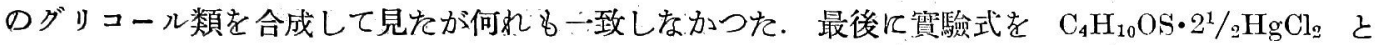
し,且つての含硫物質がアミノ酸の一種メチォンンの隥酵によつて生じたものではないかとの想像の

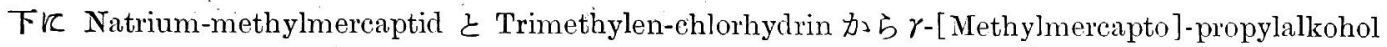
を合成した。

$$
\mathrm{CH}_{3}-\mathrm{S}-\mathrm{Na}+\mathrm{Cl}-\mathrm{CH}_{2}-\mathrm{CH}_{2}-\mathrm{CH}_{2} \mathrm{OH} \rightarrow \mathrm{CH}_{3}-\mathrm{S}-\mathrm{CH}_{2}-\mathrm{CH}_{2}-\mathrm{CH}_{2}-\mathrm{OH}
$$

この含硫アルコールの昇承複蓝と融點 $127.5 \sim 128.5^{\circ} \quad \mathrm{C}_{4} \mathrm{H}_{10} \mathrm{OS} \cdot 2^{1} /{ }_{2} \mathrm{HgCl}_{\mathrm{g}}$ の組成を有し，醬油か ら分離したものと混融しても全く融點の降下゙を見ない。

$\gamma$-[Methylmercapto]-propylalkohol は既に Bennett 及び Hock ${ }^{29}$ 並に Kirner ${ }^{3)}$ につて全く他の目 的の爲に合成されて居るものであるが，不快臭を有すと記载されて居る. 吾《の合成したものもそれ

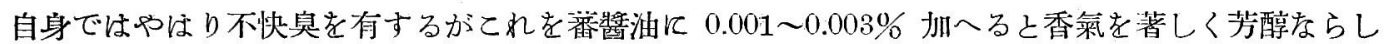

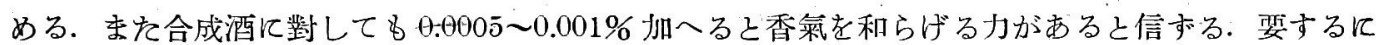
本物質は醴酵製品がその特有の芳醇な香氣を現す爲に必要な成分であると思はれる，醬油の中に存 在する $\gamma$-[Methylmercapto]-propylalkohol は Methionin の酘酵によつて生じたものであるてとは 殆ど疑ふ餘地がないと信ずるから吾々はての物質を便宜上メチオノール（Methionol）と呼ぶととに したい.

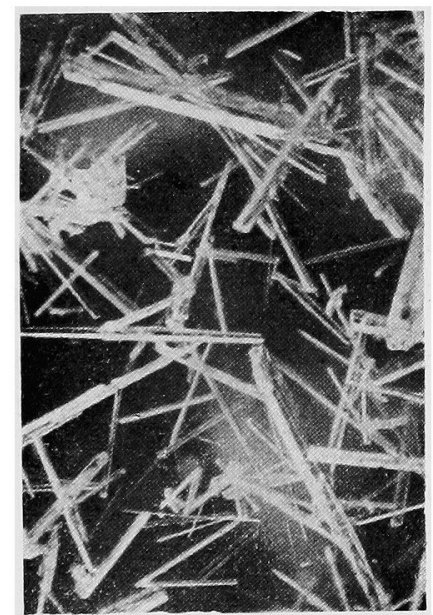

$\mathrm{C}_{4} \mathrm{H}_{10} \mathrm{OS} \cdot 2 \frac{1}{2} \mathrm{HgCl}_{2}$

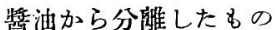

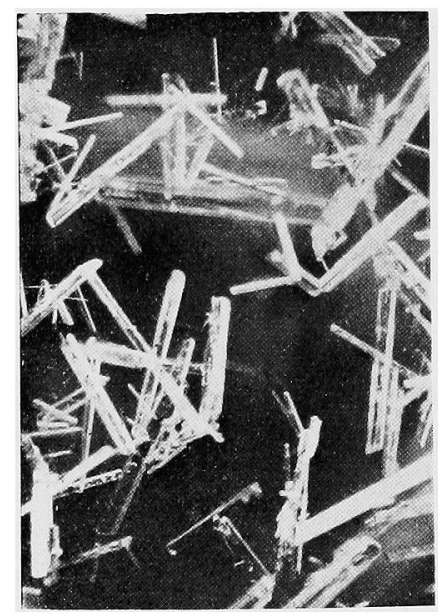

$\mathrm{C}_{4} \mathrm{H}_{10} \mathrm{OS} \cdot 2 \frac{1}{2} \mathrm{HgCl}_{2}$

合 成 品

\section{實驗 の 部}

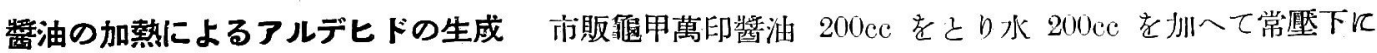
蒸溜し，溜出液 $20 \mathrm{cc}$ 每に Ripper の方法にてアルデヒドを定量した．また同樣にして得た 260cc

2) J. Chem. Soc., 1927, 2496.

3) J. Am. Chem. Soc., 50(1928), 2446. 


\begin{tabular}{|c|c|c|}
\hline 溜出液cc & $\begin{array}{l}\text { 簬一回葵溜 } \\
-\mathrm{CHOmg}\end{array}$ & $\begin{array}{c}\stackrel{\text { F }}{\text { 溜 }} \\
-\mathrm{CHO} \mathrm{mg}\end{array}$ \\
\hline 20 & 5.77 & 37.5 \\
\hline 40 & 9.19 & 40.4 \\
\hline 60 & 12.42 & 42.0 \\
\hline 100 & 19.27 & 43.3 \\
\hline 140 & 27.48 & 44.2 \\
\hline 180 & 35.40 & $44.9^{\circ}$ \\
\hline 220 & 44.6 & 45.6 \\
\hline 260 & 57.4 & 46.3 \\
\hline
\end{tabular}

の溜出液に食眮 $40 \mathrm{~g}$ を溶し水を扣へて全容 $400 \mathrm{cc}$ とした後前と同樣に蒣溜し溜出液 20 乃至 $40 \mathrm{ce}$ 每に アルデヒドを定量した。

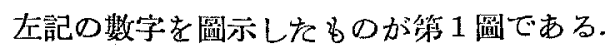

香氣物質の探取 野田酱油株式會㣂上り直接睡入し

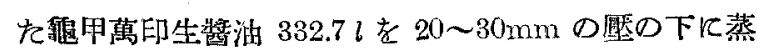
溜し, 受器を氷で泠却し原醬油の約 $1 / 3$ の溜出液を得 た. その $2 l$ 每に $500 \mathrm{~g}$ の食嗢を溶してェーテルで抽 出し，エーテルを蒸溜し去つた殘液は $3200 \mathrm{~g}$ あつた。

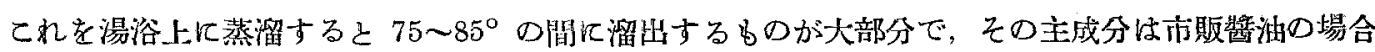
と同じくェチルアルコールである. エチルアルコールの蒸溜殘液は約 $550 \mathrm{~g}$ あつた. これを水で泠

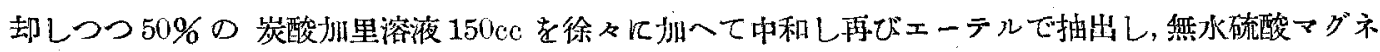
シウムで乾燥した後ェーテルを蒸溜し去つて得た中性香氣物質は $31.3 \mathrm{~g}$ あつた．この中には尚脂肪

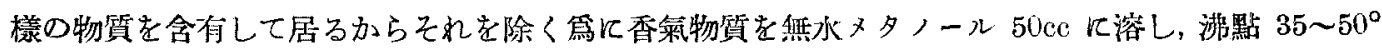

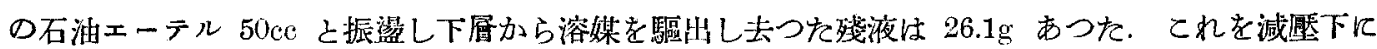
分别蒸溜して次の樣唡分に分つた.

\begin{tabular}{|c|c|c|c|}
\hline 品 分 & 渄 點 & 歷 力 $\mathrm{mm}$ & 收 量g \\
\hline I & $40^{\circ}$ 以下 & 15 & 1.7 \\
\hline II & $40 \sim 54^{\circ}$ & " & 1.5 \\
\hline III & $54 \sim 60^{\circ}$ & " & 2.2 \\
\hline IV & $60 \sim 63^{\circ}$ & $"$ & 0.8 \\
\hline $\mathrm{V}$ & $63 \sim 87^{\circ}$ & $"$ & 3.4 \\
\hline VI & $74 \sim 88^{\circ}$ & $"$ & 1.1 \\
\hline VII & $38 \sim 99^{\circ}$ & $"$ & 0.9 \\
\hline
\end{tabular}

區分 IV〜VII は硫带を合倠し，空装は 何れの區分飞含有され就. III 及 IV は 左旋性である。

$\begin{array}{ccccc} & \text { III } & \text { IV } & \text { V } & \text { VI } \\ \alpha_{D}^{190}(1 \mathrm{dm}) & -5.12^{\circ} & -0.11^{\circ} & 0 & 0\end{array}$

各區分とるフルフロールの是色反憵を示す が扠熱して探取した場合に比べると遥に弱 几. 區分 III，IV 及 $\mathrm{V}$ 亿就て炭水素の元 絜分析を行つて次の樣な結果を得た。

\begin{tabular}{|c|c|c|c|c|c|}
\hline 灆 分 & 物 質 $\mathrm{mg}$ & $\mathrm{CO}_{2} \mathrm{mg}$ & $\mathrm{H}_{2} \mathrm{O} \mathrm{mg}$ & $\mathrm{C} \%$ & H $\%$ \\
\hline III & 4.339 & 8.319 & $3.4 \overline{8} 8$ & $\tilde{0} 2.29$ & 8.92 \\
\hline$"$ & 2.633 & 5.023 & 2.125 & 52.04 & 9.03 \\
\hline$"$ & 4.310 & 8.268 & 3.497 & 52.32 & 9.08 \\
\hline IV & 3.492 & 6.642 & 2.637 & 51.88 & 8.45 \\
\hline V & 3.469 & 6.590 & 2.711 & 51.81 & 8.75 \\
\hline 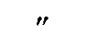 & 4.588 & 8.817 & 3.506 & 52.41 & $8 . \overline{0} \overline{0}$ \\
\hline \multirow[t]{3}{*}{$"$} & 5.820 & 11.074 & 4.483 & 51.90 & 8.62 \\
\hline & $\mathrm{C}_{4} \mathrm{H}_{8} \mathrm{O}_{2} \& し て$ & 計算值 & & 54.55 & 9.09 \\
\hline & $\mathrm{C}_{5} \mathrm{H}_{10} \mathrm{O}_{3} \& し て$ & $"$ & & 50.81 & 8.55 \\
\hline
\end{tabular}

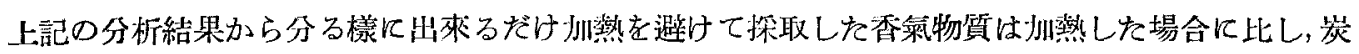
秦含量低く水素含量高いことはフルフロール含量の少レととと一致する.

區分 III 中のアセトイン及乳酸の證明 區分 III $0.4 \mathrm{~g}$ を $10 \mathrm{ce}$ の水に溶加し $20 \%$ の監化第二臷

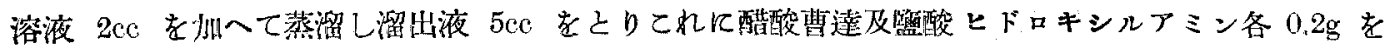


加一湯浴上に暫く溫めを後硫酸ニツヶルの 5\% 溶液少量を加へると赤色結晶性沈澱を生じた. また 區分 III 0.5g をとり $\mathrm{N}-\mathrm{NaOH} 10 \mathrm{cc}$ に溶かし荎溫に約 5 時間放置した後ェーテルで數時間連續浸出 を行ひ，非酸性物質を除いた後水層を硫酸で强酸性とし再びェーテルで約 20 時間連緬浸出を行つた. エーテル抽出液からェーテルを蒸溜し去つた殘りは䄪 $0.2 \mathrm{~g}$ 程の油狀物質であつたからこれを水に溶

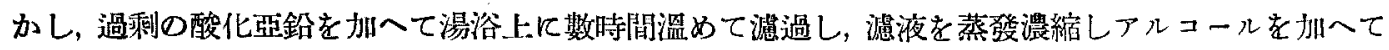

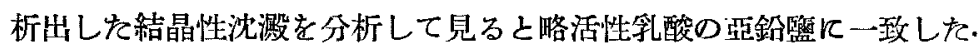

物貿 $7.058 \mathrm{mg}$ ，隇遮下に $100 \sim 105^{\circ}$ に乾燥減量 $0.932 \mathrm{mg}, \mathrm{ZnSO}_{4} 3.958 \mathrm{mg} ; \mathrm{H}_{2} \mathrm{O} 13.20 \%$, Zn $22.71 \%$

$$
\left(\mathrm{C}_{3} \mathrm{H}_{6} \mathrm{O}_{3}\right) \mathrm{Zn} \cdot 2 \mathrm{H}_{2} \mathrm{O} \text { として 計算值 } \quad 12.89 \quad 23.39
$$

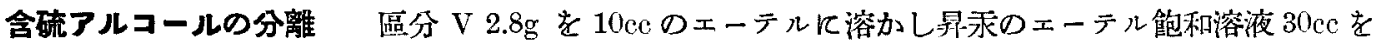

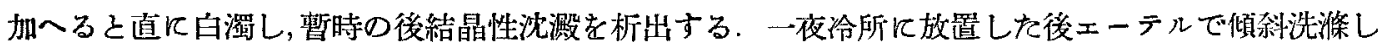
0.8g D白色結唱性粉末を得た。これを少量の溫水から再結晶を行ふと美しい稜柱狀結晶となり，再

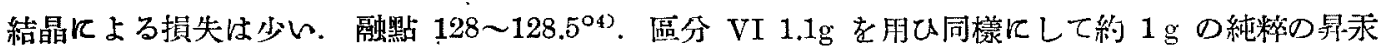
複監を得え。

水銀の定量㹥 Maixner 及 Kröcker ${ }^{5)}$ の方法で行つた.

物 質 $9.497,8.350,5.50 \mathrm{mg} ; \mathrm{Hg} \quad 6.026,5.308,3.51 \mathrm{mg} ; \quad \mathrm{Hg} \quad 63.45,63.57,63.8 \%$

物 質 $22.997,24.420,29.996 \mathrm{mg} ; \mathrm{BaSO}_{t} 6.590,6.905,8.332 \mathrm{mg}: \mathrm{S} \quad 3.94,3.88,4.04 \%$

水銀を含む有機化合物の炭水素の微量分析は未だ文獻に見ない。吾くは通常のPregl 式燃燒管に 於ける過酸化鉛の部分を金線綿で置を代〜，Hohlgranat には水を入れて沸膯せしめ, 金綿部を $100^{\circ}$

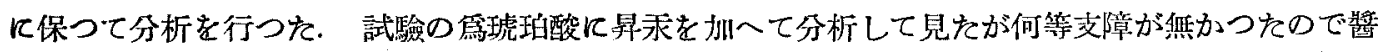
油から得た複監を分析した。

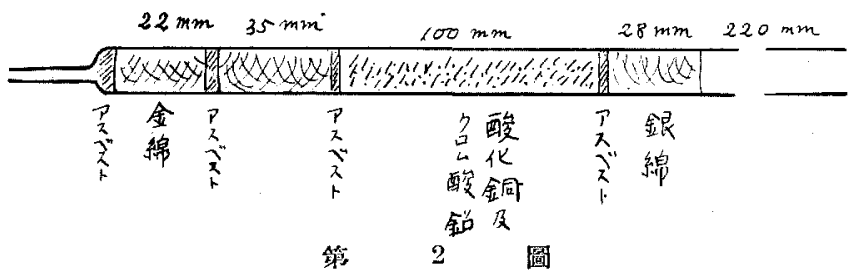

合硫アルコール昇湬複監の分折 :

\begin{tabular}{|c|c|c|c|c|}
\hline 物 質mg & $\mathrm{CO}_{2} \mathrm{mg}$ & $\mathrm{H}_{2} \mathrm{Omg}$ & C \% & $\mathrm{H} \%$ \\
\hline 19.953 & 4.520 & 2.377 & 6.18 & 1.33 \\
\hline 24.550 & 5.368 & 2.928 & 5.96 & 1.34 \\
\hline 23.908 & 5.354 & 2.918 & 6.11 & 1.37 \\
\hline 18.626 & 4.210 & 2.276 & 6.16 & 1.37 \\
\hline
\end{tabular}

$\begin{array}{ccccc} & \mathrm{C} \% & \mathrm{H} \% & \mathrm{~S} \% & \mathrm{Hg} \% \\ \text { 宽 驗 值 平均) } & 6.10 & 1.35 & 3.95 & 63.60 \\ \mathrm{C}_{5} \mathrm{H}_{12} \mathrm{O}_{2} \mathrm{~S} \cdot 3 \mathrm{HgCl}_{2} \text { として 計算 值 } & 6.31 & 1.27 & 3.37 & 63.40 \\ \mathrm{C}_{1} \mathrm{H}_{10} \mathrm{OS} \cdot 2 \frac{1}{2} \mathrm{HgCl}_{2} \text { として " } & 6.12 & 1.28 & 4.08 & 63.89\end{array}$

4）䓶報（本誌，57(1936)，275) に $130^{\circ}$ としたのは誤.

5) Mikrochemie 5(1927), 120 . 
Zeisel-Pregl 法による Methyl-marcapto 基の定量を試みたが次の如く極く一小部分の $\mathrm{CH}_{3}$-S-が $\mathrm{CH}_{3} \mathrm{~J}$ となるに過ぎないてとを知つた。

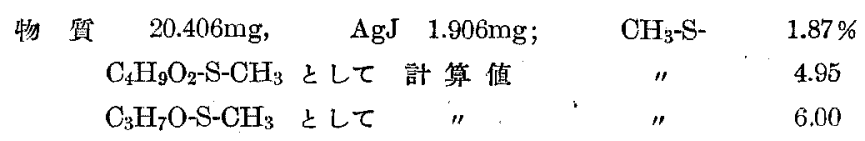

複監 $0.5 \mathrm{~g}$ をメタノールに溶かし硫化水素を通して分解し析出した硫化水銀を滤別し, 減厚下にメ

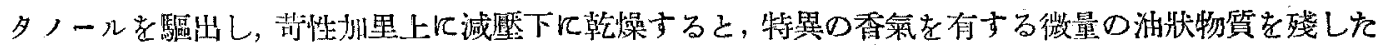
(約 $0.05 \mathrm{~g}$ ). 水下溶かして $p$-Nitrophenylhydrazin の溶液を抈ふるも沈淈を生ぜず，またアルカリと ニトロプルシドナトリウムを加へるも呈色せず, 沃度フォルム反應当全く㓌性であつた.

$\gamma$-[Methylmercapto]-propylalkohol の合成 $4.3 \mathrm{~g}$ のナトリウム $(1 モ ル)$ を然水酒精 80ce 几溶解 し, 氷で泠却しつつメチルメルカプタン $10 \mathrm{~g}$ (1.1モル) 吸收せしめね後攪挥しつつ Trimethylenchlorhydrin $16.1 \mathrm{~g}(0.9 モ ル)$ を徐そに滴下する. 加一終つた後一夜常溫に放置し常厴の下にアルコ ールを出來るだけ驅出する。殘渣をエーテルで抽出し抽出液を炭酸加里で乾燥した後エーテルを蒸 溜し去つて得た粗 $\gamma$-[Methylmercapto]-propylalkohal を減㔻蒸溜にて精製し 沸點 $60 \sim 61^{\circ} / 2.5 \sim$ $3 \mathrm{~mm}$ のbの $15 \mathrm{~g}$ を得た. 收量理論数の $83.3 \%$.

$$
\begin{aligned}
& \begin{array}{llllll}
\text { 啠 } & 0.0988 \mathrm{~g} ， \mathrm{BaSO}_{4} & 0.2143 \mathrm{~g} ; & \mathrm{S} & 29.79 \%
\end{array} \\
& \mathrm{C}_{4} \mathrm{H}_{10} \mathrm{OS} \text { として 計算值 } 30.19
\end{aligned}
$$

合成 $\gamma$-[Methylmercapto]-propylalkohol の昇永複監 $\gamma$-[Methylmercapto]-propylalkohol $エ ー テ$

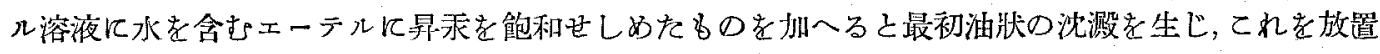
すると漸炏絈晶性になる。乙れを溫水から再絬晶すると美しい長柱狀結晶になる。融點 127.5〜

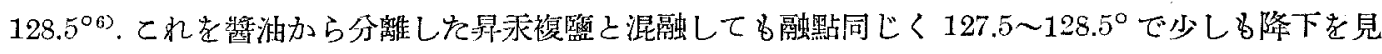
ない.

物 犋 $0.4484 \mathrm{~g}, 28.150 \mathrm{mg}, 28.078 \mathrm{~m} ; \mathrm{BaSO}_{4} .0 .1326 \mathrm{~g}, 8.078 \mathrm{mg}, 7.845 \mathrm{mg} . \quad \mathrm{S} 4.06 . \quad 3.94,3.84 \%$ $\mathrm{C}_{2} \mathrm{H}_{10} \mathrm{OS} \cdot 2 \frac{1}{2} \mathrm{HgCl}_{2}$ として 計算值 $\mathrm{S} 4.08 \%$

物 犋 $6.050 \mathrm{mg}, 6.201 \mathrm{mg}, 5.741 \mathrm{mg} ; \mathrm{Hg} 3.825 \mathrm{mg}, 3.944 \mathrm{mg}, 3.628 \mathrm{mg} ; \mathrm{Hg} 63.22,63.60 .63 .19 \%$

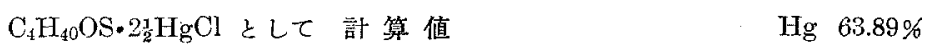

(大阪帝國大學理學部化學收室)

6) 速報（本誌 $57(1936), 275)$ に $131^{\circ}$ としたのは誤. 